\title{
Cd and Fe Concentrations of the Surface Water of a Stream in Jordan
}

\author{
Mohammed Wedyan ${ }^{1 *}$, Ahmed Al Harahsheh', Riyadh Muhaidat ${ }^{2}$ \\ Emad Bsoul', Esam Qnais ${ }^{1}$ \\ ${ }^{1}$ Biological Sciences and Biotechnology Department, The Hashemite University, Al Zarka, \\ P O Box 330127, Jordan \\ ${ }^{2}$ Biology Department, Yarmouk University, Irbid, P O Box 566, Jordan
}

Received: 18 February 2016

Accepted: 20 June 2016

\begin{abstract}
We collected 1,260 surface water samples from Al Zarqa Channelized Stream - considered to be one of the most polluted regions in Jordan due to massive discharge and accumulation of pollutants over the years. The concentrations of cadmium $(\mathrm{Cd})$ and iron $(\mathrm{Fe})$ in the stream's water were assessed to get a clear picture on the extent of pollution. Triplicate water samples weekly were randomly taken from seven different points along the channel from August 2013 to November 2014, and the concentrations of these heavy elements were determined using atomic absorption spectrophotometry (AAS). The results show that Al Zarqa Channelized Stream is slightly polluted by the heavy metals $\mathrm{Cd}$ and $\mathrm{Fe}$ in the ranges of 14.5-16 and $10-14.5 \mu \mathrm{g} / 1$, respectively. Regression analysis revealed that there was no correlation between the $\mathrm{Cd}$ and $\mathrm{Fe}$ concentrations with $\mathrm{pH}$ values of the water samples, but a significant correlation with conductivity was found. The results revealed that the concentrations of chlorophyll $a$ ranged $0.005-0.075 \mu \mathrm{g} / \mathrm{l}$. This study concludes that there is a harmful effect of heavy metals - particularly $\mathrm{Cd}$ and $\mathrm{Fe}$ - on chlorophyll content of algae. On the other hand, the data of this study suggest the necessity for re-evaluating the current environmental and water quality for health and food purposes.
\end{abstract}

Keywords: Al Zarqa Channelized Stream, heavy metal, chlorophyll $a$ content

\section{Introduction}

Marine ecosystems have been affected by various types of pollutants around the globe. Heavy metals are one of the most common contaminants in marine ecosystems [1]. Because they are toxic, non-biodegradable, and easy to accumulate in organisms, assessing heavy metals in

*e-mail: mwedyan@hu.edu.jo marine ecosystems has become a major research endeavor worldwide. Natural and anthropogenic processes (e.g., industrial waste, sewage runoff, and agricultural discharge) are primary sources of these pollutants in aquatic habitats [2-4].

In aquatic ecosystems, heavy metals can be partitioned among various environmental components (water, sediment, suspended solid, and biota) [5]. The behavior of these species depends on their specific chemical forms (dissolved to form ions or complexes, suspended as particulate matter, or deposited as bed sediment) and 
on their binding state, which influences their bioavailability, mobility, and toxicity [6]. Heavy metals are a serious threat to the structure of aquatic ecosystems because of their environmental persistence and potential capacity to bioaccumulate through food webs [7-8]. Heavy metals may affect the productivity of primary producers, which should be taken into consideration directly by inhibiting the enzymatic steps of chlorophyll biosynthesis or through induced deficiency of essential nutrients [9].

Numerous studies have focused on the increase of heavy metals concentrations resulting from anthropogenic activity in soil, water, plants, and sediments due to their deteriorating effects on water quality and aquatic biodiversity [10]. Restoration and conservation practices are thus essential steps to undertake to sustain both aquatic and terrestrial environments.

Al Zarqa Channelized Stream is one of the most polluted sites in Jordan. It is about $42 \mathrm{~km}$ long and was constructed primarily to drain water from the Kherbat AlSamra Treatment Plant to the inlet of King Talal Dam. It has also been used for fishing, farming, washing, and as a source of drinking water. Recent reports and studies provide evidence showing significant pollution of the stream by domestic and industrial activities and discharge of agricultural wastes along the channel. The flow rate upstream is very low and water in the channel is dark and has a bad odor because of the decaying organic matter during dry and hot periods of the year. The bad smell is substantiated by the sewage effluent discharge from the Kherbat Al-Samra Treatment Plant and the residential and commercial establishments into the channel. In this study on two important metals $\mathrm{Cd}$ and $\mathrm{Fe}, \mathrm{Cd}$ is rated as being a high risk and can be mobile between different environments in spite of its relative low content, while Fe is an essential micronutrient that can be harmful to living organisms at high doses [11-13]. The primary objective of the present study was to assess concentrations of particular heavy metals ( $\mathrm{Cd}$ and $\mathrm{Fe}$ ) and contamination in the $\mathrm{Al}$ Zarqa Channelized stream water. This study also aimed to investigate the relationship among these heavy metals and the algal community.

\section{Materials and Methods}

\section{Sampling Site}

We collected 1,260 surface water samples from Al Zarqa Channelized Stream (Jordan) from August 2013 to November 2014 (Fig. 1). The study area lies between $32^{\circ} 8^{\prime}-32^{\circ} 10^{\prime} \mathrm{N}$ and $36^{\circ} 10^{\prime}-36^{\circ} 0^{\prime} \mathrm{E}$. The river flows over $42 \mathrm{~km}$ until it reaches the King Talal Dam. It is considered a major surface water body that receives wastewater effluent from a sewage treatment plant. In recent years $5 \%$ of this treated water has been used in irrigation that involves the risk of exposure to pathogens.

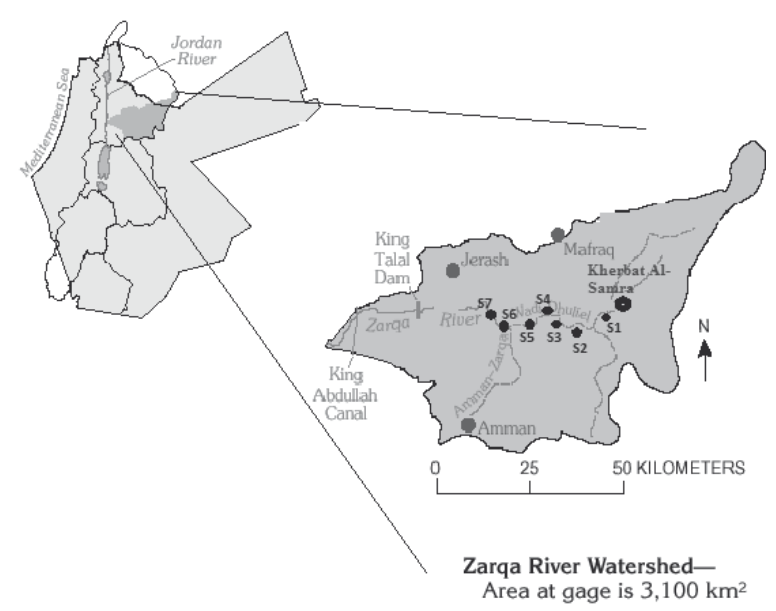

Fig. 1. Map of the study area.

\section{Sample Collection}

Surface water samples were collected weekly from different representative areas (middle of the river) marked as S1-S7 (Fig. 1). The samples were collected from a depth of $10 \mathrm{~cm}$ below the surface using a Rottner water sampler and kept in pre-cleaned acid-washed plastic containers $(5 \mathrm{~L})$ with concentrated $\mathrm{HNO}_{3}$ in order to preserve the metal and avoid precipitation. These samples were kept cooled on ice and stored in the lab at $4^{\circ} \mathrm{C}$ until analysis. All samples were collected under the same conditions in one day.

\section{Sample Analysis}

The $\mathrm{pH}$ and conductivity of the water samples were determined in the field using $\mathrm{pH}$ and conductivity meters. Concentrations of the heavy metals $(\mathrm{Cd}$ and $\mathrm{Fe}$ ) were determined using atomic absorption spectrophotometry (AAS) after digestion with $\mathrm{HNO}_{3}[14]$ and a blank solution of distilled deionized water. Background correction was applied for $\mathrm{Cd}$ and the detection limit was below $1 \mu \mathrm{g} / \mathrm{l}$ for all metals.

The photosynthetic pigments were extracted in triplicate according to Sukran et al. [15]. The concentrations of chlorophyll $a$ were calculated using the extinction coefficients and equation $\mathrm{C}_{\mathrm{a}}=11.75 \mathrm{~A}_{662}-2.350 \mathrm{~A}_{645}$ given by Sukran et al., where $\mathrm{Ca}$ is chlorophyll $a$ concentration, $\mathrm{A}_{662}$ is absorbance at $662 \mathrm{~nm}$, and $\mathrm{A}_{645}$ is absorbance at $662 \mathrm{~nm}$. The collected data were subject to statistical analysis using Microsoft Excel.

The Pearson correlation analysis was applied to examine the relationships between $\mathrm{Cd}, \mathrm{Fe}$, chlorophyll $a$ concentration, $\mathrm{pH}$, and conductivity. Analytical data quality were performed by quality control methods including the use of standard operating procedures, reagent blanks, and three sub-sample determinations. The relative standard deviations ( $\%$ RSDs) of the sub-samples were less than $8 \%$, showing good reproducibility of our analytical methods. 
Table 1. Mean of $\mathrm{pH}$ and conductivity of surface water of Al Zarqa Channelized Stream.

\begin{tabular}{|c|c|c|}
\hline Location & $\mathrm{pH}$ & Conductivity $\left(\mu \mathrm{S} \mathrm{cm}^{-1}\right)$ \\
\hline $\mathrm{S} 1$ & $8.33 \pm 0.21$ & $245 \pm 0.34$ \\
\hline $\mathrm{S} 2$ & $8.21 \pm 0.45$ & $362 \pm 0.02$ \\
\hline $\mathrm{S} 3$ & $7.95 \pm 0.27$ & $385 \pm 0.58$ \\
\hline $\mathrm{S} 4$ & $7.80 \pm 0.12$ & $257 \pm 0.45$ \\
\hline S5 & $8.12 \pm 0.025$ & $293 \pm 0.12$ \\
\hline S6 & $8.20 \pm 0.14$ & $345 \pm 0.28$ \\
\hline S7 & $8.45 \pm 0.42$ & $253 \pm 0.85$ \\
\hline
\end{tabular}

\section{Results and Discussion}

\section{Physicochemical Characteristics of the Surface Water}

The water samples analyzed in this study exhibited an alkaline $\mathrm{pH}$ range of 7.80-8.45, with an overall mean of 8.15 (Table 1). There was no difference in the recorded $\mathrm{pH}$ during the collection period and the variations in the $\mathrm{pH}$ values between the different sampling sites were also insignificant (Table 1). These results might be explained by the wastewater discharged into the canal stream that contains various alkaline matters. The observed $\mathrm{pH}$ values were within the accepted limits for drinking [16], as well as for crop production [17]. The conductivity values ranged from 245 to 485 with overall mean 306 (Table 1). These variations in the conductivity values may be due to the dilution effect; however, the location wise variation in conductivity was statistically insignificant.

\section{$\mathrm{Cd}$ and $\mathrm{Fe}$ Concentrations}

All surface water samples were analyzed for $\mathrm{Cd}$ and $\mathrm{Fe}$, with concentration ranges of 14.5-16 and $10-48.5 \mu \mathrm{g} / \mathrm{L}$, and with overall means of 15.17 and $27.18 \mu \mathrm{g} / \mathrm{L}$, respectively (Fig. 2). These results indicate that most $\mathrm{Cd}$ concentrations are higher than the MPCL recommended by JISM $(0.003 \mathrm{mg} / \mathrm{l})$. Also, the results

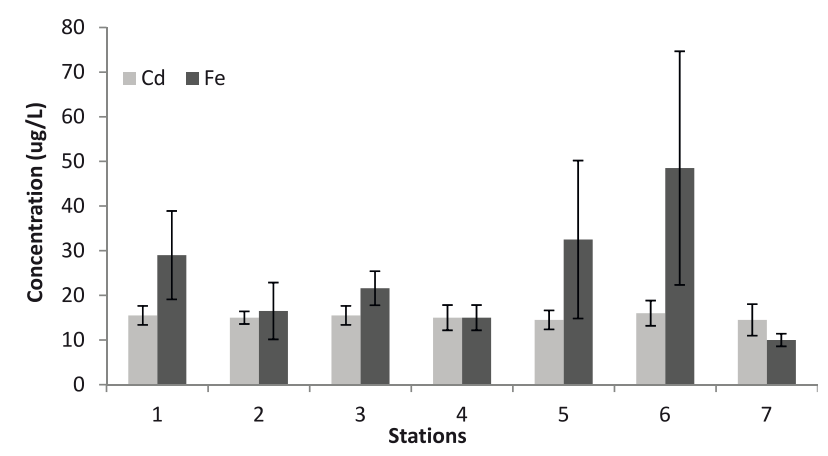

Fig. 2. Average concentrations of $\mathrm{Cd}$ and $\mathrm{Fe}$ of surface water samples (average \pm StDev). show that all Fe concentrations are lower than the MPCL recommended by JISM (1.0 mg/l) [18-19]. Comparing the results of this study with similar studies shows that the mean concentrations of $\mathrm{Cd}$ are higher than those obtained from the surface water of Ganga $(0.005 \mathrm{mg} / \mathrm{l})$ [20], while the mean concentrations of $\mathrm{Fe}$ are lower than those obtained from the same area $(0.8 \mathrm{mg} / \mathrm{l})$.

The $\mathrm{Cd}$ and $\mathrm{Fe}$ concentrations increased due to different input of drains and may show a highly significant increase during the end of summer and autumn seasons that agree with the results obtained by Bahnasawy and his team [21], and Nwabueze and Oghenevwairhe [22]. Earlier studies showed that the amount of fluctuations of anthropogenic activity, agricultural drainage water, and sewage effluents discharged into the canal are the main reasons for the temporal difference of heavy metals content [23]. On the other hand, because of the high temperature in the hot seasons and organic matter decomposition due to fermentation, the heavy metal may be liberated from the sediment to the overlying water [22].

The metal degree of pollution in the water canal is based on each individual metal's calculations. It was found that the $\mathrm{Cd}$ had a moderate effect on aquatic life compared to the data represented in a similar case study at the Ismailia Canal in Egypt [18], while the Fe exhibits a different degree of pollution for aquatic life. To estimate the metal pollution for different uses, we found the best parameter was a metal index to evaluate the concentration of each individual metal. The higher the concentration of the metal the worse the quality of water $[18,23]$. According to the metal index values, $\mathrm{Cd}$ in all selected stations was found to be threatened by the metal pollution index ranging 2.2-3.8 (MI>1). On the other hand, Fe showed less pollution effect.

The positive correlation between $\mathrm{pH}$ and conductivity of water and $\mathrm{Cd}$ and $\mathrm{Fe}$ concentrations were also noticed and the results are shown in Table 2.

There was no significant correlation between the heavy metals and $\mathrm{pH}$ of the surface water, but a significant correlation with conductivity was observed. Also, a significant positive correlation between heavy metals was noticed. These observations help to explain and understand the behavior of these metals in aquatic environments.

Table 2. Pearson correlation of $\mathrm{pH}$, conductivity, $\mathrm{Cd}, \mathrm{Fe}$, and chlorophyll $a$.

\begin{tabular}{|c|c|c|c|c|c|}
\hline & $\mathrm{pH}$ & $\begin{array}{c}\text { Conducti- } \\
\text { vity }\end{array}$ & $\mathrm{Cd}$ & $\mathrm{Fe}$ & $\begin{array}{c}\text { Chlorophyll } \\
a\end{array}$ \\
\hline $\mathrm{pH}$ & 1.00 & & & & \\
\hline $\begin{array}{c}\text { Conducti- } \\
\text { vity }\end{array}$ & -0.26 & 1.00 & & & \\
\hline $\mathrm{Cd}$ & -0.13 & 0.42 & 1.00 & & \\
\hline $\mathrm{Fe}$ & 0.05 & 0.25 & 0.64 & 1.00 & \\
\hline $\begin{array}{c}\text { Chlorophyll } \\
a\end{array}$ & -0.24 & -0.50 & -0.21 & -0.19 & 1.00 \\
\hline
\end{tabular}




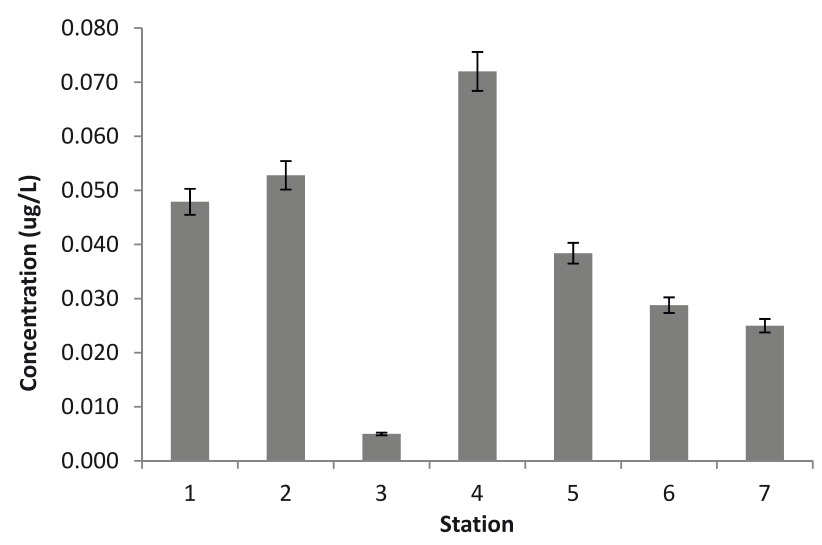

Fig. 3. Average concentrations of chlorophyll $a$ of surface water samples (average \pm StDev).

$\mathrm{Cd}$ is a toxic metal with no metabolic benefits to human and aquatic biota, and if it is present at any concentration level it indicates contamination [24]. High concentrations of Cd may lead to vomiting, diarrhea, and even death, while consuming low concentrations over a long period of time can cause kidney and bone damage [25].

Findings of this study indicate that dissolved heavy metals are indeed bioavailable within the channel stream system investigated in this study. A literature search of heavy metals concentrations revealed that the concentrations recorded in this study are comparable to highly contaminated environments, such as those exposed to urban, industrial, and mining pollution [26]. The results of this study indicate that dissolved metal bioavailability may be of the same level as in previous works $[1,26]$.

\section{Chlorophyll $a$ Concentrations of Surface Water}

The mean total chlorophyll $a$ concentration was $0.039 \mu \mathrm{g} / 1$, with a range of chlorophyll $a$ concentrations of 0.005-0.075 $\mu \mathrm{g} / 1$ (Fig. 3).

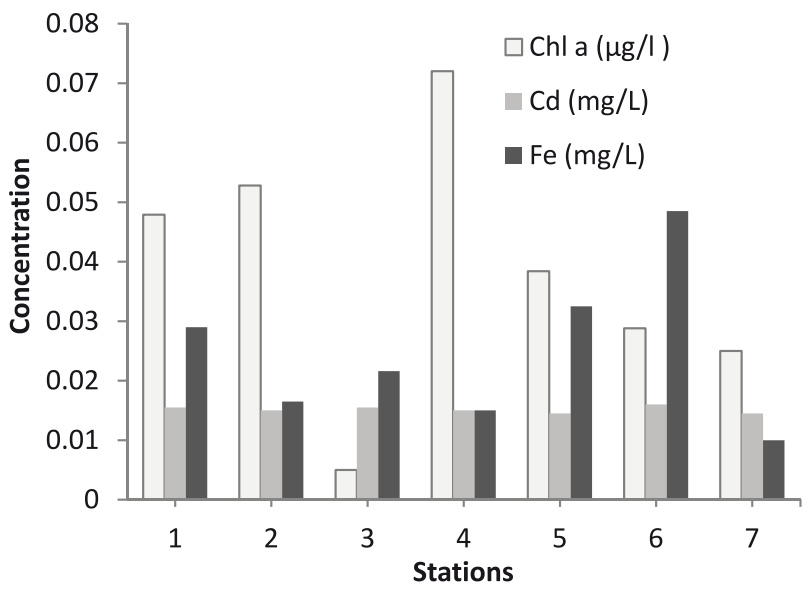

Fig. 4. Average concentrations of $\mathrm{Cd}, \mathrm{Fe}$, and Chlorophyll $a$ of surface water samples.
It is known that the major component of the photosynthetic light-harvesting system of algae is chlorophyll $a$ in the thylakoid membranes [27]. The observed results indicate that chlorophyll content increased by decreasing the concentrations of $\mathrm{Cd}$ and $\mathrm{Fe}$, which is clear in station 4 (Fig. 4). The reduction effects of heavy metals on the chlorophyll content of algae indicated not only the occurrence of damage in the thylakoids, but also disturbances in chlorophyll production [28].

The present study indicates that the heavy metals presented in different concentrations in the stream. The concentrations of $\mathrm{Cd}$ and $\mathrm{Fe}$ were above the limits of international standards. All metals may accumulate in the organisms and may cause elevated transfer to the food web, leading to serious dietary hazards. High heavy metals availability in the stream is also of concern due to the chance of leaching and contaminating nearby water bodies. This study also underscored that chlorophyll content was affected by concentrations of heavy metals.

The harmful effects of pollution on human and environmental health should be taken into consideration when there is a plan to redevelop contaminated sites into other uses, such as housing and agriculture. A number of measures can be used to reduce the heavy metal contents in the soil of the channel banks. Much precaution has to be taken, especially on the use of water from the streams and hand-dug wells around the stream as this may pose a risk to the users.

\section{Conclusion}

As Al Zarqa Channelized Stream is considered a host for various sources of waste (particularly the domestic and agricultural), it is important to monitor water quality. The stream serves as a main source of drinking and irrigation water for people living in the vicinity, and they also consume fish from the stream. With more discharge of waste effluents into the stream, the chances of greater pollution are high, as is the increasing risk to public health. It is necessary to continuously monitor the concentrations of $\mathrm{Cd}$ and $\mathrm{Fe}$ as indicators for heavy metals pollution in the surface water of the stream, in addition to increased conservation efforts by relevant organizations.

\section{Acknowledgements}

The authors are grateful to all people for providing and helping in sampling, transportation, and analysis.

\section{References}

1. ALI Z., MALIK R.N., QADIR A. Heavy metals distribution and risk assessment in soils affected by tannery effluents. Chemistry and Ecology, 29 (8), 676, 2013.

2. PRICA M., DALMACIJA B., RONCEVIC S., KRCMAR D., BECELIC M. A comparison of sediment quality results with acid volatile sulfide (AVS) and simultaneously extracted 
metals (SEM) ratio in Vojvodina (Serbia) sediments. Science of the Total Environment. 389 (2), 235, 2008.

3. ABDO M. Physico-Chemeical Studies on the Pollutants Effect in the Aquatic Environment of Rosetta Branch River Nile, Egypt. Life Science Journal, 10 (4), 2013.

4. YANG Y., CHEN F., ZHANG L., LIU J., WU S., KANG M. Comprehensive assessment of heavy metal contamination in sediment of the Pearl River Estuary and adjacent shelf. Marine Pollution Bulletin, 64 (9), 1947, 2012.

5. TUNA A.L., YILMAZ F., DEMIRAK A., OZDEMIR N. Sources and distribution of trace metals in the saricay stream basin of southwestern turkey. Environmental monitoring and assessment, 125 (1-3), 47, 2007.

6. JIANG X., TENG A., XU W., LIU X. Distribution and pollution assessment of heavy metals in surface sediments in the Yellow Sea. Marine pollution bulletin, 83 (1), 366, 2014.

7. KHALIL M.K., RADWAN A.M., EL-MOSELHY K.M Distribution of phosphorus fractions and some heavy metals in surface sediments of Burullus Lagoon and adjacent Mediterranean sea. egyptian journal of aquatic resaerch, $\mathbf{3 3}$ (1), 277, 2007.

8. SEGURA R., ARANCIBIA V., ZÚÑIGA M.C., PASTÉN P. Distribution of copper, zinc, lead and cadmium concentrations in stream sediments from the Mapocho River in Santiago, Chile. Journal of Geochemical Exploration, 91 (1), 71, 2006.

9. VAN ASSCHE F., CLIJSTERS H. Effects of metals on enzyme activity in plants. Plant, Cell \& Environment. 13 (3), 195, 1990

10. PALMA P., LEDO L., ALVARENGA P. Assessment of trace element pollution and its environmental risk to freshwater sediments influenced by anthropogenic contributions: The case study of Alqueva reservoir (Guadiana Basin). CATENA, 128, 174, 2015.

11. AGYARKO K., DARTEY E., KUFFOUR R.A., SARKODIE P.A. Assessment of Trace Elements Levels in Sediment and Water in Some Artisanal and Small-Scale Mining (ASM) Localities in Ghana. Current World Environment, 9 (1), 7 , 2014.

12. NAIR I.V., SINGH K.A.I.L.A.S.H., ARUMUGAM M., CLARSON D. Assessment of Trace Metal Pollution in Surface Water of Meenachil River at Kottayam, Kerala, India. International Journal of Earth Sciences and Engineering, $\mathbf{3}$ (5), 681, 2010.

13. KAR D., SUR P., MANDAI S.K., SAHA T., KOLE R.K. Assessment of heavy metal pollution in surface water. International Journal of Environmental Science \& Technology, 5 (1), 119, 2008.

14. AKCAY H., OGUZ A., KARAPIRE C. Study of heavy metal pollution and speciation in Buyak Menderes and Gediz river sediments. Water Research, 37 (4), 813, 2003.

15. ŞÜKRAN D., GÜNEŞ T., SIVACI R. Spectrophotometric determination of chlorophyll- $a, b$ and total carotenoid contents of some algae species using different solvents. Turkish Journal of Botany, 22 (1), 13, 1998.

16. COMMITTEE S.D.W. Drinking water and health. National Academies Press, 1, 1977.
17. FAO Manual of methods in aquatic environment research, Food and Agricultural Organization of the United Nations, Part 1: Methods of detection, measurement and monitoring of water pollution. 1975 .

18. GOHER M.E., HASSAN A.M., ABDEL-MONIEM I.A., FAHMY A.H., EL-SAYED S.M. Evaluation of surface water quality and heavy metal indices of Ismailia Canal, Nile River, Egypt. The Egyptian Journal of Aquatic Research, 40 (3), 225, 2014.

19. FRISBIE S.H., MITCHELL E.J., SARKAR B. World Health Organization increases its drinking-water guideline for uranium. Environmental Science: Processes \& Impacts, 15 (10), 1817, 2013.

20. AKTAR M.W., PARAMASIVAM M., GANGULY M., PURKAIT S., SENGUPTA D. Assessment and occurrence of various heavy metals in surface water of Ganga river around Kolkata: a study for toxicity and ecological impact. Environmental monitoring and assessment, 160 (1-4), 207, 2010. y, M., KHIDR A.A., DHEINA N. Assessment of heavy metal concentrations in water, plankton, and fish of Lake Manzala, Egypt. Turkish Journal of Zoology, 35 (2), 271, 2011.

21. NWABUEZE A., Oghenevwairhe E. Heavy metal concentrations in the west African clam, Egeria radiata (Lammark, 1804) from mciver market, warri, Nigeria. Int J Sci Nature, 3 (2), 309, 2012.

22. OMAR H.E.-D.M. Seasonal variation of heavy metals accumulation in muscles of the African Catfish Clarias gariepinus and in River Nile water and sediments at Assiut Governorate, Egypt. Journal of Biology and Earth Sciences, 3 (2), B236, 2013

23. BALAN I.N., SHIVAKUMAR M. An assessment of groundwater quality using water quality index in Chennai, Tamil Nadu, India. Chronicles of Young Scientists, 3 (2), 146, 2012.

24. OPALUWA O.D., AREMU M.O., OGBO L.O., ODIBA I.E., EKPO E.R. Assessment of heavy metals in water, fish and sediments from UKE stream, Nasarawa State, Nigeria. Current World Environment, 7 (2), 213, 2012.

25. CLEVELAND L.M., MINTER M.L., COBB K.A., SCOTT A.A., GERMAN V.F. Lead Hazards for Pregnant Women and Children: Part 1: Immigrants and the poor shoulder most of the burden of lead exposure in this country. Part 1 of a two-part article details how exposure happens, whom it affects, and the harm it can do. AJN The American Journal of Nursing, 108 (10), 40, 2008.

26. ABDO M.H. Physico- chemeical studies on the pollutants effect in the aquatic environment of rosetta branch river Nile, Egypt. Life Science Journal, 10 (4), 493, 2013.

27. SABBAGH A.A.M. Effects of heavy metals and uranium on chlorophyll, DNA, protein contents and ultrastructure of the Cyanobacterium Spirulina platensis. Department of Botany and Microbiology at the College of Science, King Saud University, 2006.

28. SPAIN A., ALM E., Implications of microbial heavy metal tolerance in the environment. 2003 